\title{
DESIGN AIDS FOR TENSION MEMBERS AS PER REVISED IS: 800- 2007
}

\author{
Hiren J. Chavda ${ }^{1}$ \\ ${ }^{1}$ Lecturer, Civil engineering department, Sir Bhavsinhji Polytechnic Institute, Bhavnagar, Gujarat, India
}

\begin{abstract}
The B.I.S. recently revised the new IS: 800-2007. This is based on limit state method. This new code includes variety in elements like tension members, compression members, flexural members, combined connection, combined axial and bending design of members. The B.I.S. has yet not published any design aids based on new IS: 800-2007. For saving time in various design of structural steel section, one need to have their own computer programme or design aids or spreadsheet which is based on IS: 8002007. In this research we have developed excel programme spreadsheet to analyze \& design tension members, which will help the structural designer to save their time in designs. Also we have prepared design aids to find out the capacity on angled tension member with single row of bolts connected to the gusset plate.
\end{abstract}

Keywords: Tension members, Design aids, IS:800-2007, Analysis, Designing, Spreadsheet, Structural steel

\section{INTRODUCTION}

\subsection{Introduction to Design of Tension Member}

Tension members are linear members in which axial forces act so as to elongate (stretch) the member. Tension members carry loads most efficiently, since the entire cross section is subjected to uniform stress. Suspenders in suspended buildings \& suspension bridge, stay cables in stayed cable in stayed bridge, bracing in bracing frame structure, tie \& purlin in roof truss and a rope are examples of the tension members.

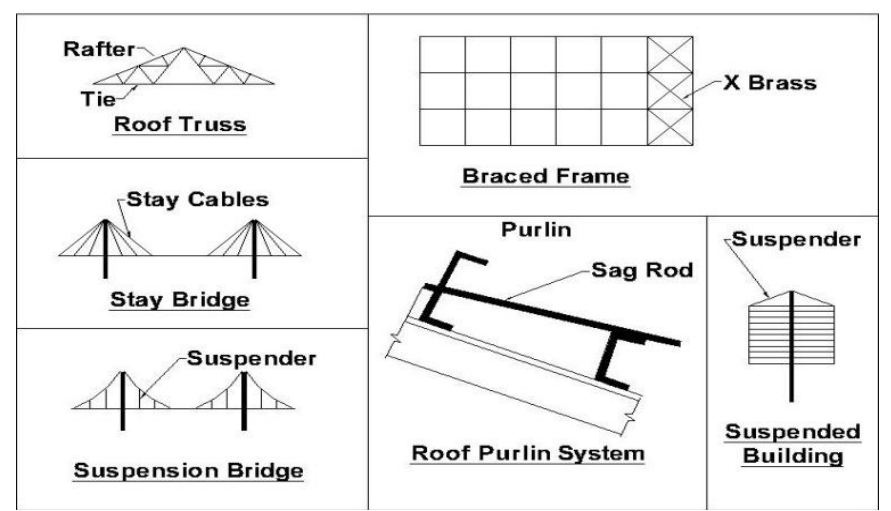

Fig -1: Tension members in structures

\section{ANALYSING AND DESIGNING OF TENSION MEMEBER}

\subsection{The Design of Tension Member as per IS: 800-} 2007

The factored design tension $\mathrm{T}$, in the members shall satisfy the following requirement: $\mathbf{T}<\mathbf{T}_{\mathbf{d}}$;

Where, $\mathbf{T}_{\mathbf{d}}=$ Design strength of the member

\subsection{Design Strength due to Yielding of Gross Section}

The design strength of members under axial tension, $\mathbf{T}_{\mathbf{d g}}$ as governed by yielding of gross section, is given by

$\mathbf{T}_{\mathbf{d g}}=\mathbf{A}_{\mathbf{g}} \mathbf{f}_{\mathbf{y}} / \boldsymbol{\gamma}_{\mathbf{m} \mathbf{0}} ;$ where, $\mathbf{f}_{\mathbf{y}}=$ yield stress of the material,

$\mathbf{A}_{\mathbf{g}}=$ gross area of cross-section, and $\boldsymbol{\gamma}_{\mathbf{m} \mathbf{0}}=$ partial safety factor for failure in tension by yielding.

\subsection{Design Strength due to Rupture of Critical} Section

\subsubsection{Plates}

The design strength in tension of a plate, $\mathbf{T}_{\mathbf{d n}}$, as governed by rupture of net cross-sectional area, at the holes is given by $\mathbf{T}_{\mathbf{d n}}=0.9 \mathbf{A}_{\mathbf{n}} \mathbf{f}_{\mathbf{u}} / \gamma_{\mathbf{m} 1}$; where, $\boldsymbol{\gamma}_{\mathbf{m} \mathbf{1}}=$ partial safety factor for failure at ultimate stress $\mathbf{f}_{\mathbf{u}}=$ ultimate stress of the material, and $\mathbf{A}_{\mathbf{n}}=$ net effective area of the member given by,

$$
A_{n}=\left[b-n_{h}+\sum_{i} \frac{p_{s i}^{2}}{4 g_{i}}\right]
$$

where, $b, \mathbf{t}=$ width and thickness of the plate, respectively,

$\mathbf{d}_{\mathbf{h}}=$ diameter of the bolt hole $(2 \mathrm{~mm}$ in additionto the diameter of the hole, in case the directly punched holes),

$\mathbf{g}=$ gauge length between the bolt holes, as shown in Fig. 2, $\mathbf{p}_{\mathbf{s i}}=$ staggered-pitch length between line of bolt holes, as in in Fig. 2, $\mathbf{n}=$ number of bolt holes in the critical section, and

$\mathbf{i}=$ subscript for summation of all the inclined legs 


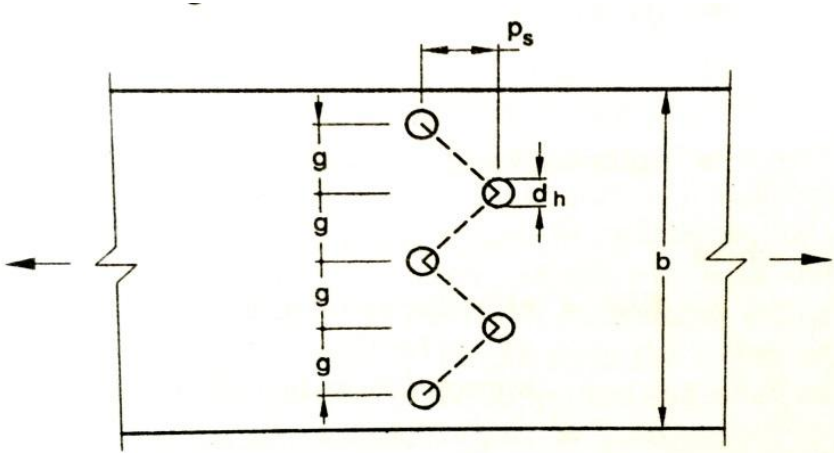

Fig -2: Plates with bolts holes in tension

\subsubsection{Threaded Roads}

The design strength of threaded rods in tension, $\mathbf{T}_{\mathbf{d n}}$, as governed by rupture is given by $\mathbf{T}_{\mathbf{d n}}=\mathbf{0 . 9} \mathbf{A}_{\mathbf{n}} \mathbf{f}_{\mathbf{u}} / \gamma_{\mathbf{m} 1}$

where, $\quad \mathbf{A}_{\mathbf{n}}=$ Net root area at the threaded section.

\subsubsection{Single Angles}

The rupture strength of an angle connected through one leg is affected by shear lag. The design strength, Tdn, as governed by rupture at net section is given by

$$
T_{d n}=0.9 A_{n} \mathbf{f}_{u} / \gamma_{m 1}+\beta A_{g o} \mathbf{f}_{y} / \gamma_{m 0}
$$

where, $\beta=1.4-0.076(w / t)\left(f_{y} / f_{u}\right)\left(b_{s} / L_{c}\right)$

$\leq\left(0.9 \mathbf{f}_{\mathrm{u}} \gamma_{\mathrm{m} 0} / \mathbf{f}_{\mathrm{y}} \gamma_{\mathrm{m} 1}\right)$

$\geq 0.7$;

where, $\mathbf{w}=$ outstand leg width, $\mathbf{b}_{\mathbf{s}}=$ shear lag width, as shown in Fig. 3, and $\mathbf{L}_{\mathbf{c}}=$ length of the end connection, that is the distance between the outermost bolts in the end joint measured along the load direction or length of the weld along the load directionor preliminary sizing, the rupture strength of net section may be approximately taken as: $\mathbf{T}_{\mathbf{d n}}=$ $\alpha A_{n} f_{u} / \gamma \mathbf{m} 1$

where, $\boldsymbol{\alpha}=\mathbf{0 . 6}$ for one or two bolts, $\mathbf{0 . 7}$ for three bolts and $\mathbf{0 . 8}$ for four or more bolts along the length in the end connection or equivalent weld length; $\mathbf{A}_{\mathbf{n}}=$ net area of the total cross-section; $\mathbf{A}_{\mathbf{n c}}=$ net area of the connected leg; $\mathbf{A}_{\mathbf{g o}}=$ Gross area of theoutstanding leg; and $\mathbf{t}=$ thickness of the leg.

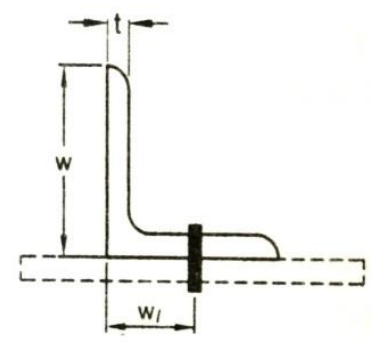

$b_{s}=w+w_{l}-t$

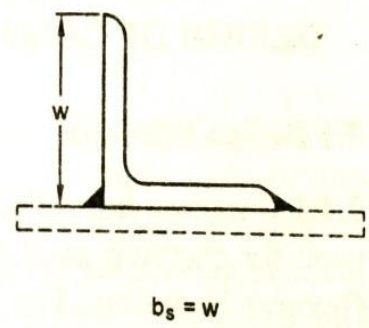

Fig -3: Angles with single leg

\subsubsection{Other Sections}

The rupture strength, $\mathbf{T}_{\mathbf{d n}}$, of the double angles, channels, Isections and other rolled steel sections, connected by one or more elements to an end gusset is also governed by shear lag effects. The design tensile strength of such sections as governed by tearing of net section may also be calculated using equation in 2.3.3, where $\boldsymbol{\beta}$ is calculated based on the shear lag distance, $\mathbf{b}$ taken from the farthest edge of the outstanding leg to the nearest bolt/weld line in the connected leg of the cross-section.

\subsection{Design Strength due to Block Shear}

The strength as governed by block shear at an end connection of plates and angles is calculated as under:

\subsubsection{Bolted Connection}

The block shear strength, $\mathbf{T}_{\mathbf{d b}}$ of connection shall be taken as the smaller of,

$$
\mathbf{T}_{\mathrm{db}}=\left[\mathbf{A}_{\mathrm{vg}} \mathbf{f}_{\mathbf{y}} /\left(\sqrt{3} \gamma_{\mathrm{m} 0}\right)+0.9 \mathbf{A}_{\mathrm{tn}} \mathbf{f}_{\mathrm{u}} / \gamma_{\mathrm{m} 1}\right]
$$

OR

$$
\mathbf{T}_{\mathrm{db}}=\left[0.9 \mathbf{A}_{\mathrm{vn}} \mathbf{f}_{\mathrm{u}} /\left(\sqrt{3} \gamma_{\mathrm{m} 1}\right)+\mathbf{A}_{\mathrm{tg}} \mathbf{f}_{\mathrm{y}} / \gamma_{\mathrm{m} 0}\right]
$$

where, $\mathbf{A}_{\mathbf{v g}}, \mathbf{A}_{\mathbf{v n}}=$ minimum gross and net area in shear along bolt line parallel to external force, respectively (1-2 and 3-4 as shown in Fig.4 (A) and 1-2 as shown in Fig. 4(B),

$\mathbf{A}_{\mathrm{tg}}, \mathbf{A}_{\mathrm{tn}}=$ minimum gross and net area in tension from the bolt hole to the toe of the angle, end bolt line, perpendicular to the line of force, respectively (2-3 as shown in Fig. 4, and $\mathbf{f}_{\mathbf{u}}, \mathbf{f}_{\mathbf{y}}=$ ultimate and yield stress of the material, respectively.

\subsubsection{Welded Connection}

The block shear strength, $\mathbf{T}_{\mathbf{d b}}$ shall be checked for welded end connections by taking an appropriate section in the member around the end weld, which can shear off as a block.

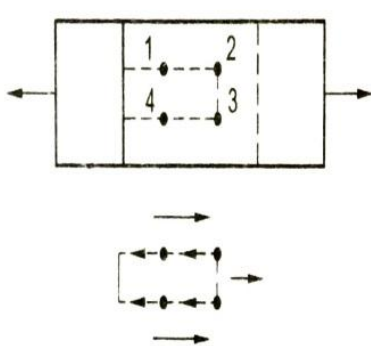

[A] PLATE

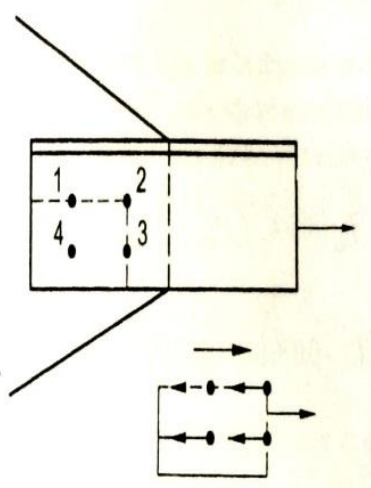

[B] ANGLE
Fig -4: Block shear failure 


\section{USER MANUAL FOR SPREAD SHEET}

\subsection{Analysis of Tension Member}

To analyze any tension member first of we need to find out below mention three strengths:
a) Design strength due to yielding of gross section
b) Design strength due to rupture of critical section
c) Design strength due to block shear

and the smallest value of the above three strengths is the design strength of tension member.

Note - As per the spread sheet designed by us, all values in yellow cells needs to be provided or selected from the drop box provided by us as given in data.

The sample excel programme spreadsheet screenshots are shown below under the description of input methodology.

\subsubsection{Design Strength due to Yielding of Gross}

\section{Section}

If we want find out design strength due to yielding of gross section, first of all we have to select the grade of steel from first yellow cell. Then we have to select the type of section from drop box. Now as per the type of section which can be angled section, plate section, box/tube section, I/wide flange section, pipe section, tee section or channeled section, we have to provide its appropriate details as the case may be like, in case of plate section we have to enter its properties like its width and thickness, similarly if angled section is selected then we have to select the size of angle from the drop box as given in data, similarly if box/tube section is selected then we have to select the size of box/tube from the drop box as given in data, similarly if I/wide flange section is selected then we have to select the size of $\mathrm{I} /$ wide flange from the drop box as given in data, similarly if pipe section is selected then we have to select the size of pipe from the drop box as given in data, similarly if tee section is selected then we have to select the size of tee from the drop box as given in data, And similarly for channeled section, select the size of channeled section as given in data from the drop box.Finally entering the above data our spread sheet will calculate the design strength due to yielding of gross section as per revised IS-800:2007.
(1) Analysis of tension member

Annexure - A

To analyze any tension member first of we need to find out below mention three strengths: (a) Design Strength Due to Yielding of Gross Section (b) Design Strength Due to Rupture of Critical Section (c) Design Strength Due to Block Shear and the smallest value of the above mentioned three strengths is the design strength of tension member. NOTE :As per the spread sheet designed by us, all values in yellow cells needs to be provided or selected from the drop box provided by us as given in data.

Part[A] : Design Strength Due to Yielding of Gross Section

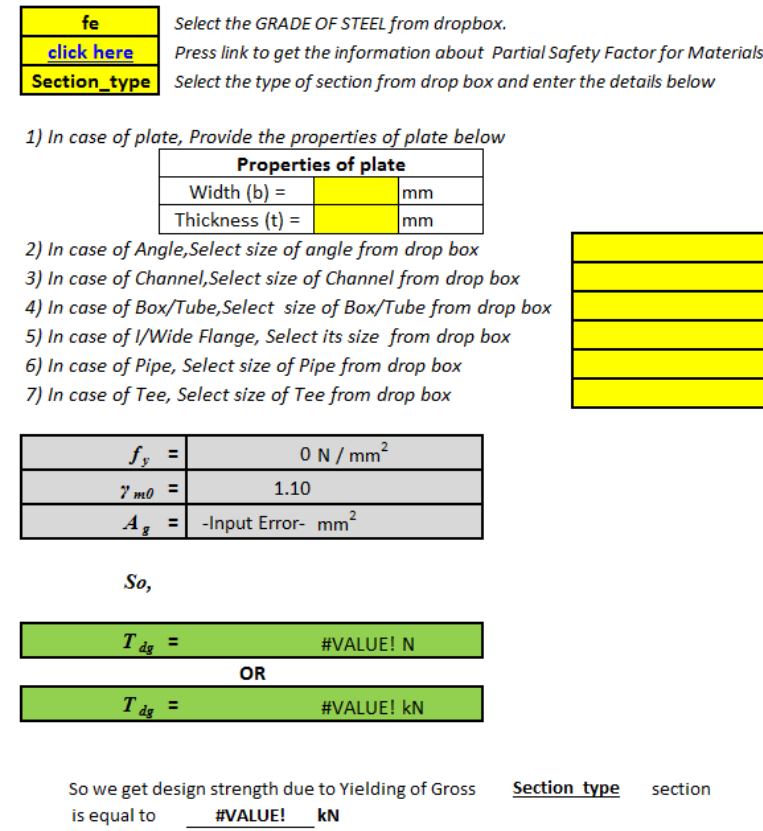

Screenshot 1: Design strength due to yielding of gross section

\subsubsection{Design Strength due to Rupture of Critical}

\section{Section}

\subsubsection{Design Rupture Strength for Plate Section}

If we want find out design rupture strength for plate section, first of all we have to select the grade of steel from dropbox, then enter the width \& thickness of plate in $\mathrm{mm}$, then after select the diameter of the bolt in mm from drop box and enter the number of bolt which are in critical section, then enter the staggered pitch length in mm, number of staggered pitch and gauge value/distance in $\mathrm{mm}$, If you want to calculate the gauge value/distance then select the "Calculate", and you already entered the gauge value/distance then select "Entered value" from dropbox. and in last select the type of clearance for fastener hole from dropbox.Finally entering the above data our spread sheet will calculate the design rupture strength for plate section as per revised IS-800:2007. 
Part[B] : Design Strength Due to Rupture of Critical Section

(1) PLATE SECTION

\begin{tabular}{|c|c|}
\hline fe & Select the GRADE OF STEEL $f$ \\
\hline & Enter the width of plate in $\mathrm{m}$ \\
\hline & Enter the thickness of plat \\
\hline 30 & Select the diameter of the \\
\hline click here & Press link to get the inform \\
\hline & Enter the number of bolt $\mathrm{v}$ \\
\hline & Enter the staggered pitch \\
\hline & Enter the number of stagg \\
\hline & Enter the gauge value/dis \\
\hline Entered value & If you want to calculate th \\
\hline $\begin{array}{c}\text { Standard } \\
\text { clearance in } \\
\text { diameter \& width } \\
\text { of slot } \\
\end{array}$ & Select the type of Clearand \\
\hline$f_{u}=$ & $0 \mathrm{~N} / \mathrm{mm}^{2}$ \\
\hline$\gamma_{m 1}=$ & 1.25 \\
\hline$b=$ & $0 \mathrm{~mm}$ \\
\hline$d_{h}=$ & $33 \mathrm{~mm}$ \\
\hline$t=$ & $0 \mathrm{~mm}$ \\
\hline$p_{s i}=$ & $0 \mathrm{~mm}$ \\
\hline$g=$ & $0.00 \mathrm{~mm}$ \\
\hline$A_{n}=$ & \#DIV $/ 0 ! \mathrm{mm}^{2}$ \\
\hline
\end{tabular}

So,

\begin{tabular}{|c|c|}
\hline$T_{d n}=$ & \#DIV/O! N \\
\hline \multicolumn{2}{|c|}{ OR } \\
\hline$T_{d n}=$ & \#DIV/0! kN \\
\hline
\end{tabular}

So we get design strength due to rupture of plate section is equal to \#DIV/0! $\mathbf{k N}$

Screenshot2: Design rupture strength for plate section

\subsubsection{Design Rupture Strength for Threaded Rods}

If we want find out design rupture strength for threaded rods, first of all we have to select the grade of steel from dropbox, then select the diameter of the bolt in $\mathrm{mm}$ from drop box.Finally entering the above data our spread sheet will calculate the design rupture strength for threaded rod as per revised IS-800:2007.

\section{(2) THREADED RODS}

\begin{tabular}{|c|}
\hline $\mathrm{Fe} 410$ \\
\hline 20 \\
\hline click here \\
\hline
\end{tabular}

Select the GRADE OF STEEL from dropbox.

Select the diameter of the bolt in $\mathrm{mm}$ from drop box

Press link to get the information about Partial Safety Factor for Materials

\begin{tabular}{|r|r|}
\hline$f_{u}=$ & $410 \mathrm{~N} / \mathrm{mm}^{2}$ \\
\hline$\gamma_{m 1}=$ & 1.25 \\
\hline$A_{n}=$ & $245.04 \mathrm{~mm}^{2}$ \\
\hline
\end{tabular}

\begin{tabular}{|c|c|}
\hline$T_{d n}=$ & $72337.06 \mathrm{~N}$ \\
\hline \multicolumn{2}{|c|}{$\mathrm{OR}$} \\
\hline$T_{d n}=$ & $72.34 \mathrm{kN}$ \\
\hline
\end{tabular}

So we get design strength due to rupture of threaded rod is equal to $\quad 72.34 \quad \mathbf{~ N N}$

Screenshot 3: Design rupture strength for threaded rods

\subsubsection{Design Rupture Strength for Single Angle}

\section{Section}

If we want find out design rupture strength for single angle section, first of all we have to select the size of angle from drop box and then select the type of connection from drop box, after selecting the type of connection enter the properties of connection like in case of welded connection enter the weld length of each side while in case of bolted connection enter the number of bolts in shear lag connection , number of bolts in critical section and the distance W1 in $\mathrm{mm}$; if you want to calculate the distance $\mathbf{W} \mathbf{1}$, then select "Calculate" and you already entered the distance W1, then select "Entered Value", then select the grade of steel, diameter of the bolt in mm from the dropbox, after that enter the thickness of gusset plate and pitch distance in $\mathrm{mm}$; if you want to calculate the pitch distance, then select "Calculate" and you already entered the pitch distance, then select "EnteredValue", now select the lag of angle connected to the plate, than select the type of clearance for fastener hole from dropbox. Finally entering the above data our spread sheet will calculate the design rupture strength for single angle section as per revised IS-800:2007.

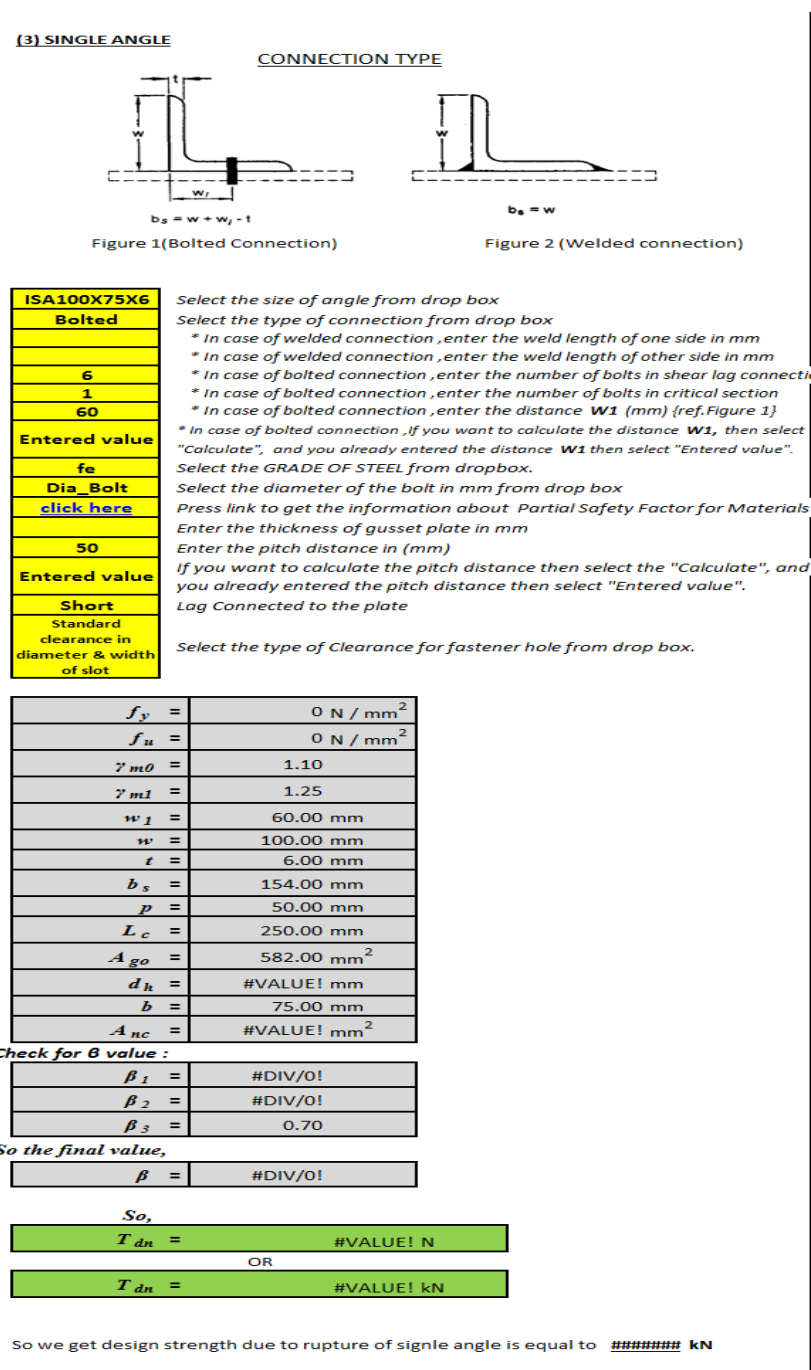

Screenshot 4: Design rupture strength for single angle section 


\subsubsection{Design Strength due to Block Shear}

If we want find out design strength due to block shear, first of all we have to select the mode of failure there were two type of failure which were indicated in the figure below the input cell, then select the grade of steel and type of section, after inputting the type of section enter the properties of that section; in case of plate enter the width \& thickness of plate in $\mathrm{mm}$ while in case of angle section select the size of angle from the dropbox provided by us, after that select the diameter of bolt in $\mathrm{mm}$ from dropbox and enter the pitch \& edge distance in $\mathrm{mm}$; if you want to calculate the pitch \& edge distance, then select "Calculate" and you already entered the pitch \& edge distance, then select "EnteredValue", then enter the thickness of gusset plate and select the lag of angle connected to the plate, after that enter the number of bolts in shear path and gauge value / distance in $\mathrm{mm}$; if you want to calculate the gauge value/ distance, then select "Calculate" and you already entered the gauge value / distance, then select "EnteredValue", than select the type of clearance for fastener hole from dropbox. Finally entering the above data our spread sheet will calculate the design strength due to block shear as per revised IS-800:2007.

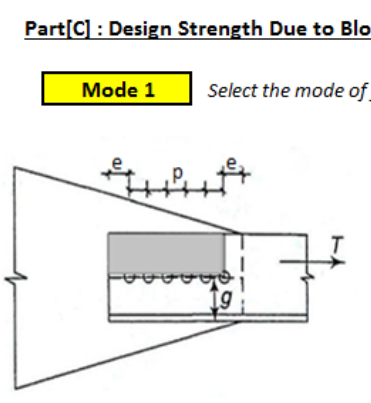

$\underline{\text { Mode } 1}$

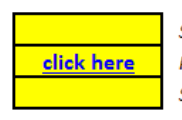

Select the GRADE OF STEEL from dropbox.

Press link to get the information about Partial Safety Factor for Materials select the type of section from drop box and enter the details below
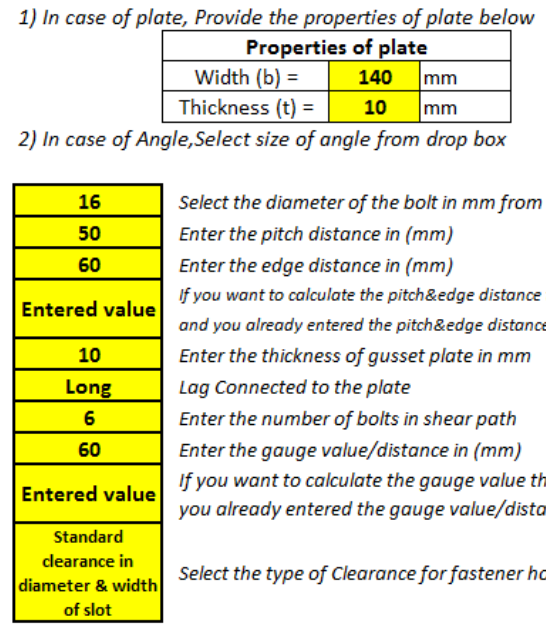

Select the diameter of the bolt in $\mathrm{mm}$ from drop box Enter the pitch distance in $(\mathrm{mm})$ Enter the edge distance in $(\mathrm{mm})$

If you want to calculate the pitch \&edge distance then select "Calculate" and you already entered the pitch \&edge distance then select "Entered value". Enter the thickness of gusset plate in $\mathrm{mm}$ Lag Connected to the plate

Enter the number of bolts in shear path Enter the gauge value/distance in ( $\mathrm{mm}$ )

If you want to calculate the gauge value then select the "Calculate", and you already entered the gauge value/distance then select "Entered value"

Select the type of Clearance for fastener hole from drop box. f slot

Screenshot 5(a): Input of Design strength due to block shear

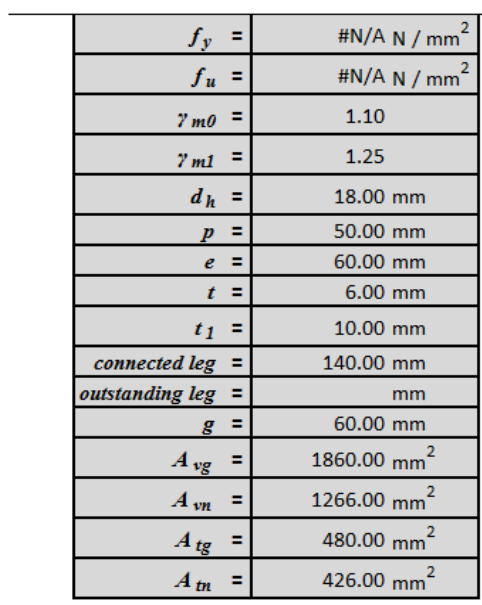

So,

\begin{tabular}{|lll|}
\hline$T_{d b 1}$ & $=$ & \\
& \#N/A N \\
\hline$T_{d b 2}=$ & & \#N/A N \\
\hline
\end{tabular}

So the Block shear strength is

$T_{d b}=\quad$ \#N/A kN

So we get Design Strength Due to Block Shear of

is equal to \#N/A kN

Screenshot 5(b): Output of Design strength due to block shear

\subsection{Design of Tension Member}

If we want design tension angled member first of all we have to select the type of angle which may be single angle or double angle from dropbox provided by us, than select the type of load for example service load or factored load, then enter the design tension strength you want to design and select unit of that, after that select the grade of steel and diameter of bold in $\mathrm{mm}$ and enter the thickness of gusset plate in $\mathrm{mm}$, now select the lag of angle which you want to design as consider as connected lag of angle to the plate , than select the type of clearance for fastener hole from dropbox. By providing these data's our spread sheet will immediately recommend two suitable angle as per your given data than we have to select one of the angle from spread sheet recommendation than we have to go for design of bolted connection ; under the bolted connection we have to enter and select the various properties of bolt and plate, first of all we have to select the grade of bold form drop box, and select the shear plate passed through bolt section and than select the type of failure and than enter the pitch \& edge distance in $\mathrm{mm}$; if you want to calculate the pitch \& edge distance, then select "Calculate" and you already entered the pitch \& edge distance, then select "Entered". Finally we will get all design data as per revised IS:8002007 provision in output table instantly and we may also check that the design is safe or unsafe below output table. 
Design of Tension member

\begin{tabular}{|c|c|}
\hline Single & Select Type of angle to be design \\
\hline Factored & Select Load Type \\
\hline \begin{tabular}{|l|l|}
200 & $\mathrm{kN}$ \\
\end{tabular} & Design Tension Strength $(T)$ \\
\hline $\mathrm{Fe} 410$ & Select the GRADE OF STEEL from dropbo \\
\hline click here & Press link to get the information about \\
\hline 10 & Thickness of gusset plate $(\mathrm{mm})$ \\
\hline 20 & Select the diameter of the bolt from dro \\
\hline Long & Lag Connected to the plate \\
\hline $\begin{array}{c}\text { Standard clearance in } \\
\text { diameter \& width of } \\
\text { slot }\end{array}$ & Select the type of Clearance for fastene \\
\hline$f_{y}=$ & $250 \mathrm{~N} / \mathrm{mm}^{2}$ \\
\hline$f_{u}=$ & $410 \mathrm{~N} / \mathrm{mm}^{2}$ \\
\hline$\gamma_{m \theta}=$ & 1.10 \\
\hline$T=$ & $200000.00 \mathrm{~N}$ \\
\hline
\end{tabular}

So Minimum Area required,

\begin{tabular}{|r|r|}
\hline$A_{g}=$ & $880.00 \mathrm{~mm}^{2}$ \\
\hline$A_{g}=$ & $968.00 \mathrm{~mm}^{2}$ \\
\hline
\end{tabular}

Suitable Sections:

1) ISA100X65X6

2) ISA100X75X6

Select size of angle you want to design

In case of Designer own choice select the size angle

Properties of Section you want to design

\begin{tabular}{|c|c|}
\hline Size of angle & ISA60X40X8 \\
\hline Depth & $60 \mathrm{~mm}$ \\
\hline WidthTop & $40 \mathrm{~mm}$ \\
\hline Thick Top & $8 \mathrm{~mm}$ \\
\hline ThickWeb & $8 \mathrm{~mm}$ \\
\hline Wt ton $/ m$ & 0.00578545 ton/m \\
\hline$W t K N / m$ & $0.0578545 \mathrm{kN} / \mathrm{m}$ \\
\hline Area & $737.00 \mathrm{~mm}^{2}$ \\
\hline
\end{tabular}

Screenshot 6 : Input for Design of tension member

\section{DESIGN AIDS}

Design aids prepared by using our excel spreadsheet to find out capacity of angled tension members with single row of bolts (2,3 or 4 nos.) connected to the gusset plate, in our spreadsheet just by changing the value of yield stress of the material $\left(\mathbf{f}_{\mathbf{y}}\right)$ and ultimate stress of the material $\left(\mathbf{f}_{\mathbf{u}}\right)$, our spreadsheet provide the designed values of design strength due to yielding of gross section ( $\mathbf{T}_{\mathbf{d g}}$ ), design strength due to rupture of critical section $\left(\mathbf{T}_{\mathbf{d n}}\right)$, design strength due to block shear $\left(\mathbf{T}_{\mathbf{d b}}\right)$, design strength of the member $\left(\mathbf{T}_{\mathbf{d}}\right)$, gauge distance $(\mathbf{g})$, diameter of hole $\left(\mathbf{d}_{\mathbf{h}}\right)$, pitch distance (p), edge distance (e) as per revised IS 800-2007 provision.

The sample of design aids is given in Annexure - B.
Capacity of angled tension members with single row of bolts connected to the gusset plate. Annexure - B Yielding Stress of member, $\mathrm{fy}=2$ 250 $\mathrm{MPa} \quad$ Ultimate Stress of member, $\mathrm{fu}=\quad 4410 \mathrm{MPa}$

\begin{tabular}{|c|c|c|c|c|c|c|c|c|c|c|c|c|c|c|c|}
\hline $\begin{array}{l}\text { Section } \\
\text { Name }\end{array}$ & $\begin{array}{c}\text { Connected } \\
\text { lag } \\
{[\mathrm{mm} \mid}\end{array}$ & $\begin{array}{l}\text { Lag } \\
\text { (mm) }\end{array}$ & $\begin{array}{l}\text { Thickness } \\
(\mathrm{mm})\end{array}$ & $\begin{array}{c}\text { Gross } \\
\text { Area } \\
\left(\mathrm{mm}^{2}\right)\end{array}$ & \begin{tabular}{|c|} 
No. \\
of \\
bolts \\
\end{tabular} & $\begin{array}{l}\text { Gauge } \\
\text { distance } \\
\text { (mm) }\end{array}$ & \begin{tabular}{|c|} 
Dia. \\
Of bolt \\
$(\mathrm{mm})$
\end{tabular} & $\begin{array}{c}\text { Dia. } \\
\text { Of hole } \\
\text { (mm) }\end{array}$ & \begin{tabular}{|l} 
Pitch \\
distance \\
(mm)
\end{tabular} & \begin{tabular}{|c} 
Edge \\
distance \\
(mm)
\end{tabular} & $\begin{array}{c}\mathrm{T}_{\mathrm{dg}} \\
(\mathrm{KN})\end{array}$ & $\begin{array}{l}\mathrm{T}_{\mathrm{dn}} \\
(\mathrm{kNN})\end{array}$ & $\begin{array}{c}\mathrm{T}_{\mathrm{ib1} 1} \\
(\mathrm{kN})\end{array}$ & $\begin{array}{c}\mathrm{T}_{\mathrm{thb2}} \\
(\mathrm{kN})\end{array}$ & $\begin{array}{c}\mathrm{T}_{\mathrm{d}} \\
\text { (kN) }\end{array}$ \\
\hline $220 \times 20 \times 3$ & 20 & 20 & 3 & 112 & 2 & 15.00 & 12 & 13.00 & 30.00 & 25.00 & 25.45 & \begin{tabular}{|l|}
18.37 \\
\end{tabular} & 20.32 & 21.56 & 18.37 \\
\hline ISA20XX20X3 & 20 & 20 & 3 & 112 & 3 & 15.00 & 12 & 13.00 & 30.00 & 5.00 & 25.45 & 20.45 & 32.13 & 30.25 & 20.45 \\
\hline ISA20X20X3 & 20 & 20 & 3 & 112 & 4 & 15.00 & 12 & 13.00 & 30.00 & 25.00 & 25.45 & 21.14 & 43.94 & 38.94 & 21.14 \\
\hline ISA20X20X4 & 30 & & 4 & 145 & 2 & 15,00 & 12 & 13,00 & 30,00 & .00 & 32.95 & 24,90 & 27,10 & 28.75 & 24,90 \\
\hline ISA20XX20X4 & 20 & 20 & 4 & 145 & 3 & 15,00 & 12 & 13,00 & 30,00 & 25,00 & 32.95 & 26.85 & 42.84 & 40,34 & 26.85 \\
\hline ISA20X20X4 & 20 & 20 & 4 & 145 & 4 & 15.00 & 12 & 13.00 & 30.00 & 25.00 & 32.95 & \begin{tabular}{|l|l|} 
\\
\end{tabular} & 58.59 & 51.93 & 27.18 \\
\hline ISA25X25X3 & 25 & & 3 & 141 & 2 & 15.00 & 12 & 13.00 & 30.00 & 00 & 32.05 & 24.10 & 24.75 & 24.97 & 24.10 \\
\hline ISA25X25X3 & 25 & 2 & 3 & 141 & 3 & 15.00 & 12 & 13.00 & 30.00 & 25.00 & 32.05 & 27.91 & 36.56 & 33.66 & 27.91 \\
\hline ISA25X25X3 & 25 & 2 & 3 & 141 & 4 & 15.00 & 12 & 13.00 & 30.00 & 25.00 & 32.05 & \begin{tabular}{|l|}
29.19 \\
\end{tabular} & 48.37 & 42.35 & 29.19 \\
\hline ISA25X25X4 & 2 & & 4 & 184 & 2 & 15.00 & 12 & 13.00 & 30.00 & 25.00 & 41.82 & 33.81 & 33.00 & 33.29 & 33.00 \\
\hline ISA25X25X4 & 25 & 2 & 4 & 184 & 3 & 15.00 & 12 & 13.00 & 30.00 & 25.00 & 41.82 & 37.45 & 48.75 & 44.88 & 37.45 \\
\hline ISA25X25X4 & 2 & & 4 & 184 & 4 & 15.00 & 12 & 13.00 & 30.00 & 25.00 & 41.82 & \begin{tabular}{|l|}
388.66 \\
\end{tabular} & 64.49 & 56.47 & 38.66 \\
\hline ISA25XX2XX5 & 25 & 25 & 5 & 225 & 2 & 15.00 & 12 & 13.00 & 30.00 & 25.00 & 51.14 & 42.91 & 41.25 & 41.62 & 41.25 \\
\hline ISA25X25X5 & 25 & & 5 & 225 & 3 & 15.00 & 12 & 13.00 & 30.00 & 25.00 & 51.14 & 46.36 & 60.93 & 56.10 & 46.36 \\
\hline ISA25X25X5 & 25 & 25 & 5 & 225 & 4 & 15,00 & 12 & 13,00 & 30,00 & 25,00 & 51,14 & $47,26 \mid$ & 80,61 & 70.59 & 47.26 \\
\hline ISA30X20X3 & 30 & 20 & 3 & 141 & 2 & 20.00 & 12 & 13,00 & 30,00 & 25,00 & 32,05 & 26.58 & 24.75 & 24,97 & 24.75 \\
\hline ISA30XX0X3 & 30 & 2 & 3 & 141 & 3 & 20.00 & 12 & 13.00 & 30.00 & 25.00 & 32.05 & 28.98 & 36.56 & 33.66 & 28.98 \\
\hline ISA30X20X3 & 30 & 20 & 3 & 141 & 4 & 20.00 & 12 & 13.00 & 30.00 & 25.00 & 32.05 & 29.78 & 48.37 & 42.35 & 29.78 \\
\hline ISA30X20X4 & 30 & & & 184 & 2 & 20.00 & 12 & 13.00 & 30.00 & 25.00 & 41.82 & \begin{tabular}{|l|}
36.07 \\
\end{tabular} & 33.00 & 33.29 & 33.00 \\
\hline ISA30X2OX4 & 30 & 20 & 4 & 184 & 3 & 20.00 & 12 & 13.00 & 30.00 & 25.00 & 41.82 & 38.35 & 48.75 & \begin{tabular}{|l|}
44.88 \\
\end{tabular} & 38.35 \\
\hline ISA30X20X4 & 30 & 20 & 4 & 184 & 4 & 20.00 & 12 & 13.00 & 30.00 & 25.00 & 41.82 & \begin{tabular}{|l|}
38.98 \\
\end{tabular} & 64.49 & 56.47 & 38.98 \\
\hline ISA30X20X5 & 30 & 20 & 5 & 225 & 2 & 20.00 & 12 & 13.00 & 30.00 & 25.00 & 51.14 & 44.94 & 41.25 & 41.62 & 41.25 \\
\hline ISA30X20X5 & 30 & 20 & 5 & 225 & 3 & 20.00 & 12 & 13.00 & 30.00 & 25.00 & 51.14 & \begin{tabular}{|l|}
47.09 \\
\end{tabular} & 60.93 & 56.10 & 47.09 \\
\hline ISA30X20X5 & 30 & 20 & 5 & 225 & 4 & 20.00 & 12 & 13.00 & 30.00 & 25.00 & 51.14 & 47.25 & 80.61 & 70.59 & 47.25 \\
\hline ISA30X30X3 & 30 & 30 & 3 & 173 & 2 & 20.00 & 12 & 13.00 & 30.00 & 25.00 & 39.32 & \begin{tabular}{|l|}
38.99 \\
\end{tabular} & 24.75 & 24.97 & 24.75 \\
\hline ISA30X30X3 & 30 & 30 & 3 & 173 & 3 & 20,00 & 12 & 13,00 & 30,00 & 25,00 & 39,32 & \begin{tabular}{|l|}
33.88 \\
\end{tabular} & 36.56 & 33,66 & 33.66 \\
\hline ISA30X30X3 & 30 & 30 & 3 & 173 & 4 & 20,00 & 12 & 13,00 & 30,00 & 25,00 & 39,32 & 36.23 & 48,37 & 42,35 & 36.23 \\
\hline
\end{tabular}

Screenshot 7: Design aids to find capacity of angled tension memberswith single row of bolts. (Annexure - B)

As shown in screenshot 7 , we prepared design aids to find capacity of angled tension members with single row of bolts (2,3 or 4 nos.)of each angled section.

\section{CONCLUSION}

The revised IS 800-2007 has given number of formula for design a tension member which is time consuming. In this research the spreadsheet has been prepared for following purposes:

- To analyze/design the tension capacity of angle section.

- Analyze tension capacity of given angle section.

- Design tension member for given tensile force.

- Design of simple bolted connection.

- Finally a design aids is given in ready reference tabulated format for various angle section.

\section{FUTURE SCOPE}

- Design of tension member using various section like channel section, T-section, plate section etc.

- Design of HSFG bolt can be included.

- Tension member using welding connection.

- Two, three or more row can be considered in spreadsheet.

- $\quad$ Revision of SP-6 can be done by now IS 800-2007.

- A GUI based computer programme can be prepared by using visual basic or visual $\mathrm{C}++$

- Android Mobile application also can be prepared. 


\section{ACKNOWLEDGEMENTS}

The authors would like to thank the Bureau of Indian standard (BIS, New Delhi) whose provide valuable code for steel structure.

\section{REFERENCES}

[1] IS: 800-2007- code of practice for general solution in steel, Bureau of Indian Standards, New Delhi, December 2007.

[2] Steel Structures design and practice by N.Subramanian, 3rd impression, oxford higher education, New Delhi, 2012.

[3] Limit stater design of Steel Structure by S K Duggal, First Edition, Tata McGraw Hill, New Delhi, 2011

[4] Design of Steel Structures- By Limit State Method as Per IS: 8002007 by S S Bhavikatti, Second Edition, I K International Publishing House, 2011.

[5] INSDAG guider for the structural use of steelwork in buildings by Dr. Rangachari Narayanan and, Dr.Kalyanraman. Kolkata, March 2003.

[6] Design of Steel Structures by K S Sai Ram, Pearson Education publication, 2010.

[7] Design of steel structures by Prof. S.R.Satish Kumar and Prof. A.R.Santh Kumar,Indian institute of technology Madras.

[8] Handbook for structural engineers SP-6(1).

[9] IS 808:1989-code of Dimensions for hot rolled steel beam, column, channel and angle sections.

[10] IS 1367 (Part 1): Technical supply conditions for threaded steel fasteners.

\section{BIOGRAPHIES}

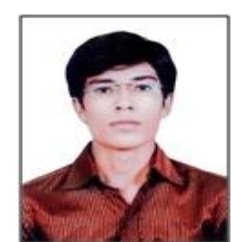

Mr.Hiren J. Chavdawas born in 1991 in Bhavnagar, Gujarat. He receives his Bachelor of Engineering degree in Civil Engineering from Govt. Engg. College Bhavnagar, Gujarat Technological University in 2013. At present he is working as a Lecturer in Sir Bhavsinhji Polytechnic Institute Bhavnagar. 